Article

\title{
Smart Urban Mobility System Evaluation Model Adaptation to Vilnius, Montreal and Weimar Cities
}

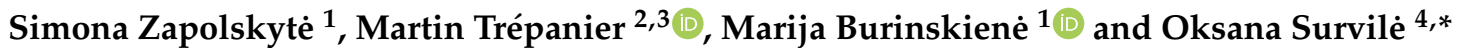 \\ 1 Department of Roads, Faculty of Environmental Engineering, Vilnius Gediminas Technical University, \\ LT-10223 Vilnius, Lithuania; simona.zapolskyte@vilniustech.lt (S.Z.); marija.burinskiene@vilniustech.lt (M.B.) \\ 2 Department of Mathematics and Industrial Engineering, Polytechnique Montréal, \\ Montréal, QC H3C 3A7, Canada; mtrepanier@polymtl.ca \\ 3 Interuniversitary Research Centre on Enterprise Networks, Logistic and Transportation (CIRRELT), \\ Montréal, QC H3T 1J4, Canada \\ 4 Department of Environment Protection and Water Engineering, Faculty of Environmental Engineering, \\ Vilnius Gediminas Technical University, LT-10223 Vilnius, Lithuania \\ * Correspondence: oksana.survile@vilniustech.lt; Tel.: +370-69-98-0153
}

\section{check for}

updates

Citation: Zapolskytè, S.;

Trépanier, M.; Burinskienè, M.; Survilè, O. Smart Urban Mobility System Evaluation Model Adaptation to Vilnius, Montreal and Weimar Cities. Sustainability 2022, 14, 715. https://doi.org/10.3390/su14020715

Academic Editors: Chiara Garau, Claudia Yamu, Vicenza Torrisi,

Michela Tiboni and

Margarida Coelho

Received: 22 December 2021

Accepted: 5 January 2022

Published: 10 January 2022

Publisher's Note: MDPI stays neutral with regard to jurisdictional claims in published maps and institutional affiliations.

Copyright: (c) 2022 by the authors. Licensee MDPI, Basel, Switzerland. This article is an open access article distributed under the terms and conditions of the Creative Commons Attribution (CC BY) license (https:/ / creativecommons.org/licenses/by/ $4.0 /)$.

\begin{abstract}
To date, there is no developed and validated way to assess urban smartness. When evaluating smart city mobility systems, different authors distinguish different indicators. After analysing the evaluation indicators of the transport system presented in the scientific articles, the most relevant and influential indicators were selected. This article develops a hierarchical evaluation model for evaluating a smart city transportation system. The indicators are divided into five groups called "factors". Several indicators are assigned to each of the listed groups. A hybrid multi-criteria decision-making (MCDM) method was used to calculate the significance of the selected indicators and to compare urban mobility systems. The applied multi-criteria evaluation methods were simple additive weighting (SAW), complex proportional assessment (COPRAS), and technique for order preference by similiarity to ideal solution (TOPSIS). The significance of factors and indicators was determined by expert evaluation methods: the analytic hierarchy process (AHP), direct, when experts evaluate the criteria as a percentage (sum of evaluations of all criteria 100\%) and ranking (prioritisation). The evaluation and comparison of mobility systems were performed in two stages: when the multi-criteria evaluation is performed according to the indicators of each factor separately and when performing a comprehensive assessment of the smart mobility system according to the integrated significance of the indicators. A leading city is identified and ranked according to the smartness level. The aim of this article is to create a hierarchical evaluation model of the smart mobility systems, to compare the smartness level of Vilnius, Montreal, and Weimar mobility systems, and to create a ranking.
\end{abstract}

Keywords: benchmarking; multi-criteria analysis; smart city; smart urban mobility system; sustainable mobility; MCDM; evaluation model

\section{Introduction}

With the rapid development of technology, the world's cities and their inhabitants are becoming increasingly smart. This trend encourages the development of a variety of smart technological solutions for the public service infrastructure in cities. In order to implement the principles of sustainable development in the field of smart technologies and to ensure a better quality of life [1-3], each city must find the most rational way to adapt and use smart systems [4] in the living environment of the future.

Environmentally unfriendly and inefficient transport has many unintended consequences for cities: deteriorating quality of life, declining labour productivity, increasing energy consumption, congestion, increasing air pollution, and threats to personal safety [5,6]. Insufficiently modernised mobility system infrastructure reduces the speed of transport 
and increases the number of accidents in cities. One of the most important elements of the mobility system infrastructure is regulated intersections. Improperly set phases and time intervals that are not adapted to changing traffic conditions increase the problems caused by congestion. The growth in the number of vehicles, the disruption of public transport (downtime, delays), increased accidents, and air pollution show that the city needs to modernise its transport infrastructure. The malfunctioning of the mobility system directly affects the city's residents and guests, the environment, and businesses. To ensure the smooth movement of people, goods, and services [7,8], the transport system must be competitive and cost-effective. Therefore, each city must adopt the development and modernisation of the mobility system rationally. Various technological solutions ensure the social and economic well-being of the population. One of the most important aspects of growing cities is connectivity $[8,9]$. The importance of mobility and its impact on other aspects of a smart city, such as sustainability, the economy, and life, make this issue vital for citizens and local authorities. The urban mobility system consists of road infrastructure, vehicles, policies, and regulations. The development of urban mobility infrastructure aims to mitigate climate change while ensuring the vital movement of people, goods and services, and social equality in the choice of quality travel. Urban travel patterns should not be detrimental to human health and the environment [10]. One of the differences between mobility and smart mobility is the ability to access information in real time, save time and money, improve travel, and reduce carbon dioxide (CO2) emissions. Mobility is one of the most difficult topics facing cities. It covers both environmental and economic aspects and requires high-tech and decent human behaviour [11]. Smart mobility is related to urban planning, which focuses on collective modes of transportation through extensive use of information and communication technologies. Therefore, it is necessary to formulate a comprehensive concept of the smart mobility system and to select the indicators of smartness that characterise it [12].

The main contribution of this article is the selected factors and indicators for the evaluation of the smart urban mobility system that define the smartness level of the mobility system. Numerical values of factors and indicators significance were calculated. A practically applicable multi-criteria evaluation methodology of the urban mobility system is proposed.

This study aims to compare the smartness level of urban mobility systems using MCDM methods according to selected evaluation criteria. The second chapter of this study reviews the scientific literature related to the use of MCDM methods and the criteria for assessing smart mobility systems. In the third chapter, the factors and indicators for assessing smart urban mobility systems are selected. In the fourth chapter, the numerical values of the significance of the selected factors and indicators are calculated by expert evaluation methods: AHP [12], direct [13], and ranking [14]. The summarised significance of factors and indicators is used to evaluate the smart mobility system. Multi-criteria assessment methods are applied to the evaluation of smart mobility systems: SAW [12], COPRAS [12], and TOPSIS [12]. The smartness levels of the mobility systems of three cities Vilnius (Lithuania), Montreal (Canada), and Weimar (Germany) are compared, and the priority line is formed.

\section{Literature Review}

\subsection{Methods}

Multi-criteria decision-making (MCDM) methods are an important tool for solving engineering problems. To this day, there is a wide selection of MCDM methods. There is a problem in choosing the most appropriate method for solving your task. There is no single MCDM method that can guarantee the accuracy of a solution to a problem. Zavadskas [15] performed an analysis of MCDM methods that showed that AHP and TOPSIS are among the best-known methods.

More accurate results can be obtained using the hybrid MCDM method [16]. This method is most commonly used when dealing with large amounts of information to solve 
complex problems. In this way, two tasks can be performed: calculating the significance of the selected indicators and integrating them into the value of the multi-attribute utility function [17]. For computational reliability, the use of a hybrid MCDM method is proposed.

In this study, the generalised significance of factors and indicators calculated by AHP [12], direct [13], and ranking [14] methods are used. In this study, multi-criteria assessment methods are applied to the evaluation of the smart mobility systems, SAW [12], COPRAS [12], and TOPSIS [12], using generalised values of factors and indicators. Weights for multi-criteria evaluation criteria are based on expert judgement, i.e., expert evaluations provide the basis for determining subjective criteria weights. The opinions of individual experts are often contradictory. That is to say, the importance and priority ranking of individual expert criteria evaluation will vary.

Expert methods are used to determine the significance of the indicators. The evaluation of experts is influenced by their qualifications, work experience, and specificity, as well as their interest in obtaining certain results. The criteria weights calculated from the submitted evaluations can be used in a multi-criteria evaluation if the expert opinions are statistically consistent. Five questionnaires were prepared for expert evaluation to evaluate individual indicators of factors and the sixth for evaluation of factors. The experts filled in the questionnaires using three methods: ranking the factors/indicators, directly evaluating the factors /indicators as a percentage (100\% in total), and filling in the paired comparison tables compiled using the AHP method.

The experts were selected strictly according to their competence in the fields of transportation and civil engineering. These are the heads of the following institutions: $\mathrm{ME}$ "Susisiekimo paslaugos" for transport services in Vilnius City (3), Lithuanian Road Administration under the Ministry of Transport and Communications (1), the Ministry of Transport and Communications of the Republic of Lithuania (1), Vilnius Gediminas Technical University (VILNIUS TECH) Road Research Institute staff with a scientific degree (3), researchers from the Department of Roads, Faculty of Environmental Engineering, VILNIUS TECH (5), and researchers from the VILNIUS TECH Faculty of Transport Engineering (2). A total of 15 experts were interviewed one by one or in exceptional cases in small groups, as the AHP method is quite complicated and requires an explanation by an interviewer [12].

\subsection{Review of Smart City Mobility System Indicators}

Many scientific publications can be found on the smart city transport system. However, there are not many articles that provide indicators for evaluating the mobility system. In this work, 45 scientific publications (which provide smart mobility assessment indicators) were reviewed in order to create a hierarchical evaluation model of mobility system indicators. Most publications on mobility system evaluation indicators were found by Italian researchers-10; by Greece, Spain, Indonesia, Canada, and China-4; by Australia, India, and Poland-2; and by Ireland, Brazil, Japan, Colombia, the United Kingdom, the Netherlands, Pakistan, the Czech Republic, and Hungary-1 publication. According to the year of publication of the reviewed publications, it can be concluded that the interest in the smart city transport system is growing (Figure 1). 


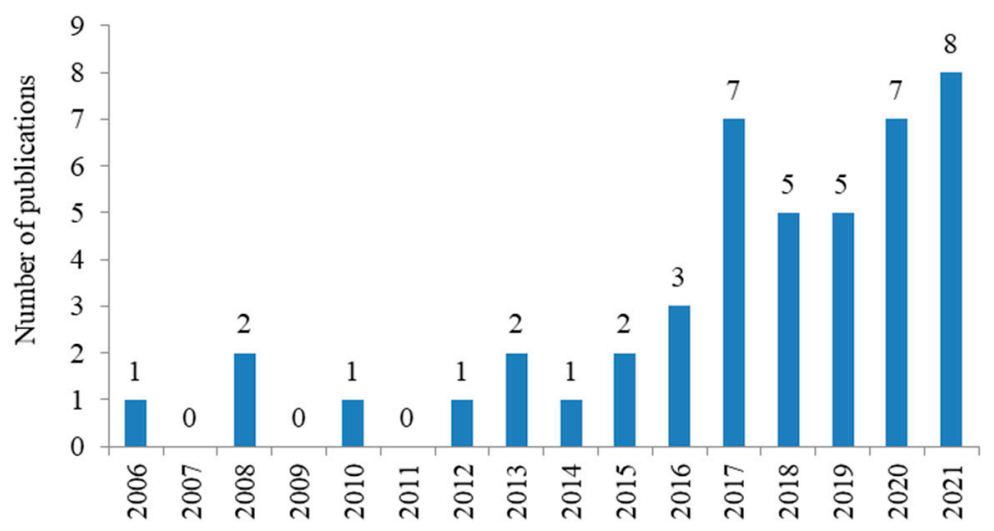

Figure 1. Number of reviewed publications by year [18].

Researchers distinguish different indicators in research on the mobility system. Some authors divide them into groups, usually when there are many of the indicators $[1,2,7,8,10,19-40]$; others do not group indicators [3-6,41-51]. It has been observed that indicators are not grouped when all aspects of a smart city are examined, and not just the mobility system. However, some authors do not group the indicators by researching the mobility system alone. In the articles reviewed, researchers use a set of different indicators. The number of indicators used in the research also varies from four [46] or six indicators $[27,44,49]$ up to 81 [36].

Savelson et al. [35] in a scientific publication on sustainable transport in Nova Scotia presents 20 sustainable transport indicators divided into four groups. Appleton et al. [19] present 17 smart transport policy indicators divided into four groups. T. Litman's [29] article on sustainable transport system indicators presents a set of 30 indicators divided into nine groups. Jiang et al. [28] provide 26 indicators for the development of a sustainable urban transportation system divided into six groups to assess public transport services in Chinese cities. Debnath et al. [25] propose a comprehensive and practical framework for com-paring the intelligence of urban transport systems according to 21 indicators divided into three groups. Boselli et al. [23] present a set of 16 indicators divided into three groups using a multi-criteria decision-making approach to smart mobility system evaluation. Benevolo et al. [11] present 52 indicators of smart mobility as part of smart city indicators. The paper explores the role of ICT in supporting advanced mobility, with its impact on quality of life and society. The indicators are divided into five groups. Garau et al. [26] describe the methodology for evaluating the transport system in Cagliari and suggest actions that could be taken in the light of international best transport practices. The methodology consists of 18 indicators divided into six groups. Sdoukopoulos et al. [48] present 16 indicators of sustainable urban mobility that can be assessed using social media data. Tafidis et al. [36] present an effective and comprehensive system of indicators as a tool for evaluating the mobility system consisting of 81 indicators. The indicators are divided into eight groups. Costa et al. [24] present 22 indicators divided into seven groups for the evaluation of urban public transport. Lopez-Carreiro and Monzon [30] provide a methodology based on the establishment of quantitative indicators called the intelligent transport index. The methodology is based on 16 indicators divided into four groups. Battarra et al. [21] explore smart mobility in Italian cities. It uses 28 indicators and three factors for benchmarking. Bat-tarra et al. [22] provide an assessment of smart mobility measures for older people. The evaluation is based on 27 indicators, which are divided into seven groups. Balducci and Ferrara [20] present 28 indicators divided into three categories to form a taxonomy of intelligence. The study by Orlowski and Romanowska [32] presents 16 indicators of the intelligent transport system divided into four groups. Nagy et al. [8] reviewed the smart city transport system and the quality elements of its services. The study uses 17 indicators divided into three groups. Sharifi et al. [1] examine tools for assessing the inclusion of smart city indicators in the scale of sustainability. The mobility 
system is evaluated according to 39 indicators divided into six factors. Paiva et al. [7] provide a three-level hierarchical evaluation system for the smart mobility system. At the first level, there are six indicators, at the second level 17, and at the third level six. Quiroga et al. [2] analyse the current situation of the smart mobility system in Colombia and other cities (Madrid-Spain, Lisbon-Portugal, and Paris-France) using 13 criteria divided into four factors.

The most common indicators of the communication system in the literature are shown in Figure 2.

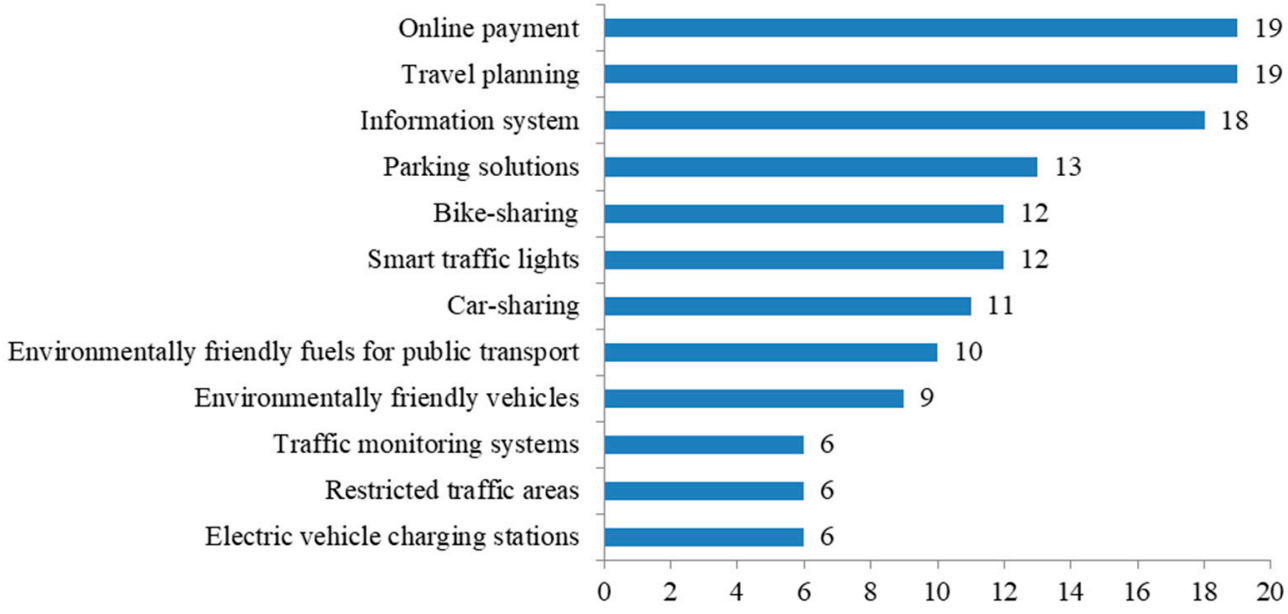

Figure 2. The most common indicators of the smart mobility system in the literature.

An analysis of the literature has shown that researchers integrate different assessment indicators. Some authors use differently named indicators of the same value.

\section{Evaluation Criteria of the Smart Mobility System}

The indicators presented in scientific publications were used to select the indicators for the evaluation of the smart mobility system. The indicators were selected according to a hierarchical system (Figure 3) consisting of three levels.

$\begin{gathered}\text { Primary } \\ \text { indicators }\end{gathered}>\begin{aligned} & \text { Secondary } \\ & \text { indicators }\end{aligned}>>\begin{aligned} & \text { Final } \\ & \text { indicators }\end{aligned}$

Figure 3. Hierarchical structure of selection of evaluation indicators.

Primary indicators are indicators found in scientific publications, regardless of their recurrence. The names of the indicators with the same meaning have been harmonised. Duplicate indicators were eliminated, leaving one at a time. Thus, a set of secondary indicators has been compiled, which does not contain repetitive or otherwise named indicators with the same meaning.

Following the recommendations of the European Commission documents and taking into account the indicators provided by the researchers, a set of final indicators was developed-22 indicators, excluding indicators that are irrelevant to the study and have little impact. The importance and impact of the indicators on the smart mobility system have been discussed with experts in the field through meetings and discussions through online platforms.

Five factors were selected to structure the hierarchical evaluation model of the smart mobility system, according to which the indicators are evaluated. For clarity, a label is assigned to each factor.

A. motor travel and congestion reduction measures;

B. pollution abatement measures; 
C. travel safety and accident reduction measures;

D. traffic management tools and services;

E. smart infrastructure measures.

Each factor was assigned indicators that will be used as criteria for evaluating the cities. The label for the indicators was selected according to the factor to which they were assigned.

A1. Car sharing. Vehicle rental services that substitute for private automobile ownership [11,20-22,26,27,34];

A2. Bike sharing. Bike rental services that substitute for private automobile ownership $[11,20-22,26,27,34,42]$;

A3. Low-power electric vehicle sharing. Low-power electric vehicle rental services that substitute for private automobile ownership [11];

A4. Carpooling. Also called ridesharing, the purpose of the system is to bring together the users, who travel in the same direction with the same vehicle [11,21,22];

A5. Park and ride system. Park and ride facilities are parking lots with public transport connections that allow commuters and other people heading to city centres to leave their vehicles and transfer to a bus, rail system, or carpool for the remainder of the journey $[11,20,36]$;

B1. Use of alternative fuels and renewable energy sources in the public transport. The alternative to fossil fuels: electricity, liquefied gas, methane, hydrogen, biodiesel, and fuel cells $[11,19,20,30,36,43]$;

B2. Environmentally friendly private vehicles. These include electric, hydrogen vehicles, and others that use alternative fuels rather than fossil fuels [11,20,21,36,43,52];

B3. Modern parking solutions. These are the parking lots with a routing system and/or reservation of parking space [11,25,27,32,34,37,42,47,49];

B4. Emissions testing and mitigation. The system uses advanced sensors to monitor areas of polluted air and control access to such areas [11,25];

C1. Smart pedestrian and bicycle crossings. Built-in hardware detects pedestrians and activates roadside light panels and vertical panels on either side of the road and sensor-driven cycling signal management, creating green waves [22,42,47];

C2. Smart speed reduction. Sensors of the automatic speed reduction system detect when the number of cars exceeds the set limits on the streets and automatically reduce the speed limit $[11,36,53]$;

C3. Traffic monitoring systems. The travel safety system helps create a safe environment for passengers, drivers, and support staff. The sensors monitor the environment in the vehicles, stations, parking lots, and basic transit infrastructure $[22,25,37,53]$;

C4. Autonomous vehicles. The equipment installed in the cars tracks the environment, has databases of the road and surrounding areas that are constantly scanned. The system provides information to the driver and helps drive safely. Autonomous driving is also possible in some sections [11,44];

D1. Traffic lights management systems. Controlled and coordinated or adaptive control traffic lights, automatically controlled in response to traffic conditions or upon the request of pedestrians [11,20,21,26,32,42,44,52];

D2. Vehicular communication systems. Vehicle-to-everything (V2X) system components monitor the environment. The system incorporates vehicle-to-vehicle (V2V) and vehicle-to-infrastructure (V2I) technologies, which detect and prevent potential obstacles and alert other road users. 5G internet connectivity provides autonomous car development opportunities [21,25,37];

D3. Information, travel planning, and online payment. Electronic ticketing on-board, interactive information on routes, timetables and waiting times, travel planner for optimal routes, dedicated website for travel tickets [20-22,30,32,34,42,46,52];

D4. Variable information and message signs. Automatic road signs (variable message), SMS traffic alerts, electronic payment of parking, dedicated info applications for mobile devices, and real-time public transport information [20-22,26,32,34,42,49,52]; 
E1. Special traffic lanes. Only vehicles meeting the lane marking requirements (buses, high-occupancy, electric cars, and taxis) can drive in these lanes. Smart special lanes must be equipped with sensors to detect offenders-the Automatic Number Plate Recognition (ANPR) system is used [11,21];

E2. Restricted traffic zones. Smart restricted traffic zones capture vehicles entering the area. If the system does not find a specific vehicle on the list of vehicles allowed to enter the area, a fine will be imposed [11,20-22];

E3. Electric vehicles charging stations and hydrogen stations. These include electric vehicles charging and hydrogen filling stations and other smart electric vehicles charging applications [11,20,27,53];

E4. Smart street surfacing. These are the surfaces of the street specially equipped: illuminated, heated, de-icing, charging electric vehicles, etc.;

E5. Smart street lighting. Smart street lighting controls work with climatic conditions, time of the day, traffic volume, and more. The main advantage of this system is the centralised control of all luminaries connected to the system, remote lighting-level change, and information on luminary malfunctions, pavement, and traffic conditions [20,22,34].

After selecting the evaluation factors and indicators, the structure of the hierarchical evaluation model of the smart urban mobility system was created (Figure 4).

\begin{tabular}{|c|c|c|}
\hline \multirow{5}{*}{\multicolumn{2}{|c|}{ vel and }} & A1 (Car sharing) \\
\hline & & A2 (Bike sharing) \\
\hline & & A3 (Low-power electric vehicle sharing) \\
\hline & & A4 (Carpooling) \\
\hline & & A5 ("Park and Ride"system) \\
\hline \multirow{4}{*}{\multicolumn{2}{|c|}{ 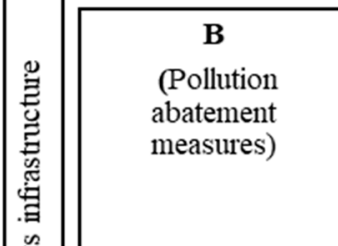 }} & $\begin{array}{l}\text { B1 (Use of alternative fuels and renewable energy sources in } \\
\text { public transport) }\end{array}$ \\
\hline & & B2 (Environmentally friendly vehicles) \\
\hline & & B3 (Modern parking solutions) \\
\hline & & B4 (Emissions Testing and Mitigation) \\
\hline \multirow{8}{*}{ 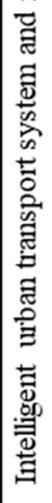 } & \multirow{4}{*}{\begin{tabular}{|c|}
$\mathbf{C}$ \\
(Travel safety and \\
accident reduction \\
measures)
\end{tabular}} & C1 (Smart pedestrian and bicycle crossings) \\
\hline & & C2 (Smart speed reduction) \\
\hline & & C3 (Traffic monitoring systems) \\
\hline & & C4 (Autonomous vehicles) \\
\hline & \multirow{4}{*}{\begin{tabular}{|c|}
$\mathbf{D}$ \\
(Traffic \\
management tools \\
and services)
\end{tabular}} & D1 (Traffic light management system) \\
\hline & & D2 (Vehicular communication systems) \\
\hline & & D3 (Information, travel planning and online payment) \\
\hline & & D4 (Variable information and message signs) \\
\hline & \multirow{5}{*}{$\begin{array}{c}\mathbf{E} \\
\text { (Smart } \\
\text { infrastructure } \\
\text { measures) }\end{array}$} & E1 (Special traffic lanes) \\
\hline & & E2 (Restricted traffic zones) \\
\hline & & E3 (Electric vehicles charging stations, hydrogen stations) \\
\hline & & E4 (Smart street surfacing) \\
\hline & & E5 (Smart street lighting) \\
\hline
\end{tabular}

Figure 4. Structure of the hierarchical evaluation model of smart urban mobility system. 


\section{Results}

\subsection{Calculating the Importance of Factors and Indicators}

The importance of the factors and indicators are calculated using the three methods above: AHP, direct assessment, and ranking. The generalised values of factors and indicators were calculated using the average method (Table 1).

Table 1. Numerical values of the importance of factors and indicators.

\begin{tabular}{|c|c|c|c|c|c|c|c|c|c|c|c|c|}
\hline \multirow{3}{*}{ 总 } & \multirow{3}{*}{ 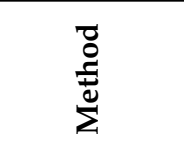 } & \multirow{3}{*}{$\frac{\mathscr{E}}{\frac{\Xi}{\nu}}$} & \multirow{3}{*}{ : } & \multirow{3}{*}{ 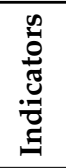 } & \multicolumn{6}{|c|}{ Method } & \multirow{2}{*}{\multicolumn{2}{|c|}{ Generalised }} \\
\hline & & & & & \multicolumn{2}{|c|}{ AHP } & \multicolumn{2}{|c|}{ Direct } & \multicolumn{2}{|c|}{ Ranking } & & \\
\hline & & & & & Value & Place & Value & Place & Value & Place & Value & Place \\
\hline \multirow{5}{*}{ A } & AHP & 0.2645 & 1 & A1 & 0.1703 & 4 & 0.2020 & 3 & 0.1911 & 4 & 0.1878 & 4 \\
\hline & Direct & 0.2360 & 1 & A2 & 0.2163 & 2 & 0.2080 & 2 & 0.2178 & 2 & 0.2140 & 2 \\
\hline & Ranking & 0.2488 & 1 & A3 & 0.1825 & 3 & 0.1887 & 4 & 0.2000 & 3 & 0.1904 & 3 \\
\hline & \multirow{2}{*}{ Generalised } & \multirow{2}{*}{0.2498} & \multirow{2}{*}{1} & A4 & 0.0962 & 5 & 0.1380 & 5 & 0.1378 & 5 & 0.1240 & 5 \\
\hline & & & & A5 & 0.3347 & 1 & 0.2633 & 1 & 0.2533 & 1 & 0.2838 & 1 \\
\hline \multirow{4}{*}{ B } & AHP & 0.1506 & 4 & B1 & 0.3840 & 2 & 0.3520 & 2 & 0.3333 & 2 & 0.3564 & 2 \\
\hline & Direct & 0.1547 & 4 & B2 & 0.4359 & 1 & 0.3593 & 1 & 0.3467 & 1 & 0.3806 & 1 \\
\hline & Ranking & 0.1600 & 4 & B3 & 0.0924 & 3 & 0.1360 & 4 & 0.1533 & 4 & 0.1272 & 4 \\
\hline & Generalised & 0.1551 & 4 & B4 & 0.0877 & 4 & 0.1527 & 3 & 0.1667 & 3 & 0.1357 & 3 \\
\hline \multirow{4}{*}{$\mathrm{C}$} & AHP & 0.2045 & 3 & $\mathrm{C} 1$ & 0.3065 & 2 & 0.3037 & 2 & 0.2867 & 2 & 0.2806 & 2 \\
\hline & Direct & 0.2073 & 3 & $\mathrm{C} 2$ & 0.3253 & 1 & 0.3711 & 1 & 0.3133 & 1 & 0.3098 & 1 \\
\hline & Ranking & 0.2044 & 3 & $\mathrm{C} 3$ & 0.1664 & 4 & 0.1371 & 4 & 0.1933 & 4 & 0.1886 & 4 \\
\hline & Generalised & 0.2054 & 3 & $\mathrm{C} 4$ & 0.2018 & 3 & 0.1881 & 3 & 0.2067 & 3 & 0.2211 & 3 \\
\hline \multirow{4}{*}{$\mathrm{D}$} & AHP & 0.2422 & 2 & D1 & 0.3936 & 1 & 0.3093 & 1 & 0.3333 & 1 & 0.3454 & 1 \\
\hline & Direct & 0.2367 & 2 & D2 & 0.3613 & 2 & 0.3007 & 2 & 0.3067 & 2 & 0.3229 & 2 \\
\hline & Ranking & 0.2356 & 2 & D3 & 0.1424 & 3 & 0.2127 & 3 & 0.2000 & 3 & 0.1850 & 3 \\
\hline & Generalised & 0.2382 & 2 & D4 & 0.1026 & 4 & 0.1773 & 4 & 0.1600 & 4 & 0.1466 & 4 \\
\hline \multirow{5}{*}{$\mathrm{E}$} & AHP & 0.1383 & 5 & E1 & 0.3296 & 1 & 0.2733 & 1 & 0.2400 & 1 & 0.2810 & 1 \\
\hline & Direct & 0.1653 & 5 & E2 & 0.2137 & 2 & 0.2233 & 2 & 0.2356 & 2 & 0.2242 & 2 \\
\hline & Ranking & 0.1511 & 5 & E3 & 0.176 & 3 & 0.1713 & 4 & 0.2044 & 3 & 0.1839 & 3 \\
\hline & \multirow{2}{*}{ Generalised } & \multirow{2}{*}{0.1516} & \multirow{2}{*}{5} & E4 & 0.16297 & 4 & 0.1707 & 5 & 0.1244 & 5 & 0.1527 & 5 \\
\hline & & & & E5 & 0.1177 & 5 & 0.1613 & 73 & 0.1956 & 4 & 0.1582 & 4 \\
\hline
\end{tabular}

Rank weights calculated by the AHP, direct, and ranking methods are different, so the results are shown in the diagram (Figure 5).

Figure 5 shows that, when calculating the significance of factors and indicators by different methods, different numerical values of significance are obtained in each case. The scatter of the numerical values of the significance of the indicators calculated by the AHP method is the largest and differs significantly from the others. The results calculated by the direct and ranking methods are closer than those calculated by the AHP method. Although the significance and rankings of the indicators do not coincide in all respects, the upward and downward trends of the curve remain very similar. 


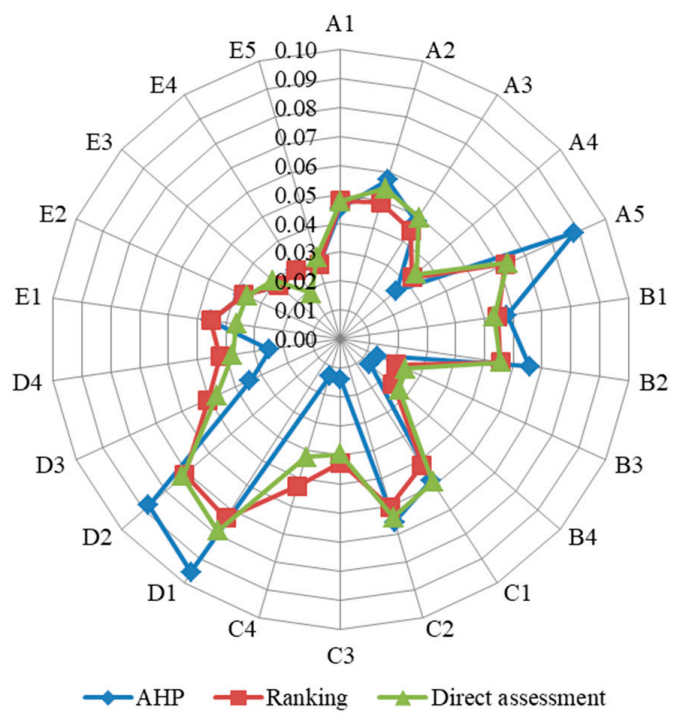

Figure 5. Integrated significance of indicators calculated by AHP, ranking, and direct evaluation methods [18].

When filling in the questionnaires, the experts assessed not only the significance of the indicators but also the significance of each factor. In order to comprehensively identify the city with the smartest urban mobility system, it is necessary to integrate the significance of each factor and its indicators. To calculate the significance of integrated indicators, Saaty [54] recommended a method called synthesis. Using this method, the calculated significance of each indicator is multiplied by the significance of the factor to which it belongs (Figure 6).

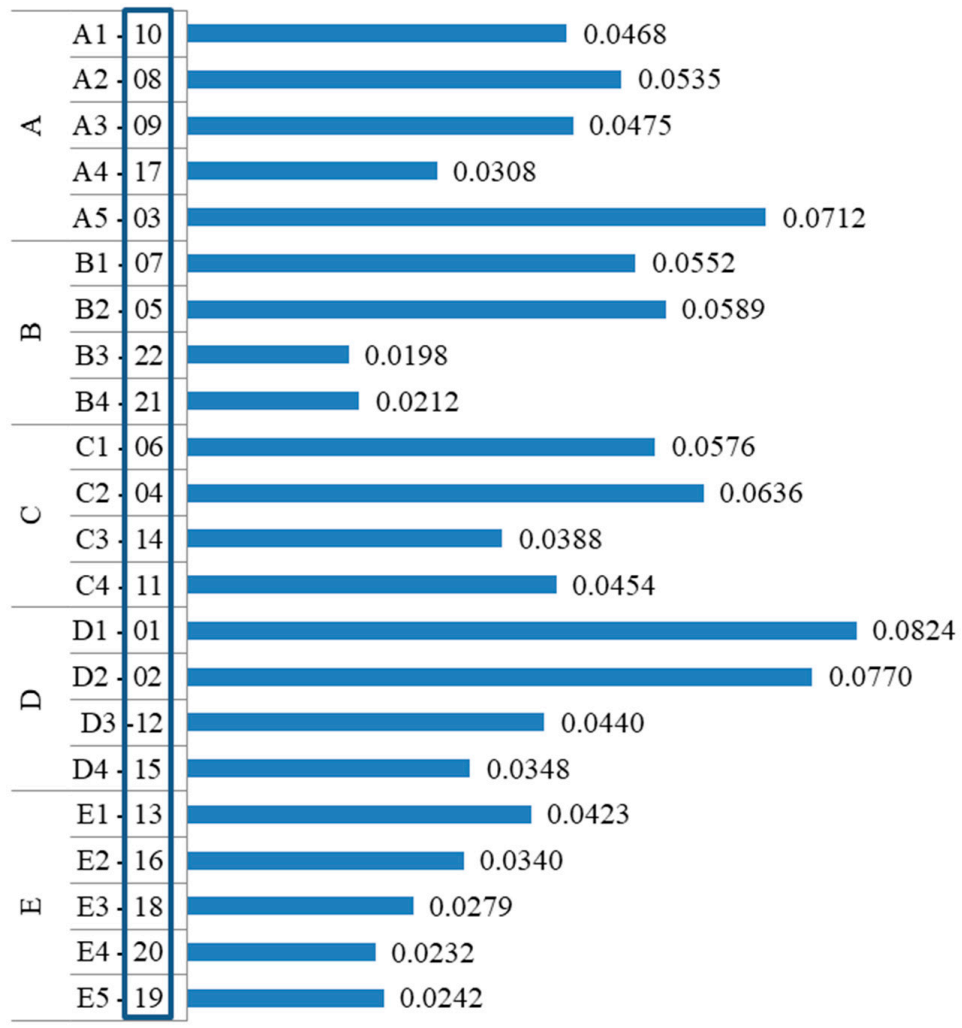

Figure 6. The integrated significance of the indicators is summarised [18]. 
After calculating the generalised significance of the integrated indicators and ranking them, it was found that the indicator "traffic lights management system" $(0.08236)$ has the greatest influence on the evaluation of the smart mobility system, then indicator "vehicular communication systems" (0.07697). The indicators with the least impact are "modern parking solutions" (0.01983) and "emissions testing and mitigation" (0.02116).

\subsection{Evaluation of Smart Urban Mobility System}

The cities chosen for the smart mobility system comparison differ not only in terms of population, area, and population density (Table 2) but also in terms of their economic and geographical location.

Table 2. Data of compared cities.

\begin{tabular}{cccc}
\hline Parameters & Vilnius & Weimar & Montreal \\
\hline Population & 559,421 & 65,098 & $2,014,221$ \\
\hline $\begin{array}{c}\text { Population density } \\
\left(\text { inhabitants } / \mathrm{km}^{2}\right)\end{array}$ & 1395.1 & 770.4 & 4259.4 \\
\hline Area $\left(\mathrm{km}^{2}\right)$ & 401 & 84.5 & 473 \\
\hline
\end{tabular}

The study sought to compare a larger number of cities. According to the developed evaluation model, the data required for the study are not open data. In order to collect all the data, it was necessary to go to the selected cities and communicate with the authorities disposing of the data. This task was hampered by a pandemic. The aim was to find contact with the staff of the relevant city authorities. Unfortunately, all data were obtained only from Vilnius, Weimar, and Montreal. Incomplete data sets were not suitable for the study.

The smart mobility system of cities Vilnius, Weimar, and Montreal were compared according to each factor. Results for comparison of alternatives were calculated by MCDM methods SAW, COPRAS, and TOPSIS (Table 3).

Table 3. Comparison of Vilnius, Weimar, and Montreal smart mobility systems by factors.

\begin{tabular}{|c|c|c|c|c|c|c|c|c|c|}
\hline \multirow{3}{*}{ Factor } & \multirow{3}{*}{ City } & \multicolumn{6}{|c|}{ MCDM Method } & \multirow{3}{*}{$\begin{array}{c}\text { Average } \\
\text { Value }\end{array}$} & \multirow{3}{*}{$\begin{array}{l}\text { Genera } \\
\text { Positior }\end{array}$} \\
\hline & & \multicolumn{2}{|c|}{ SAW } & \multicolumn{2}{|c|}{ COPRAS } & \multicolumn{2}{|c|}{ TOPSIS } & & \\
\hline & & Value & Place & Value & Place & Value & Place & & \\
\hline \multirow{3}{*}{ A } & Vilnius & 0.4959 & 1 & 0.3343 & 2 & 0.3387 & 2 & 0.3896 & 2 \\
\hline & Weimar & 0.3155 & 3 & 0.3177 & 3 & 0.5432 & 3 & 0.3921 & 3 \\
\hline & Montreal & 0.4432 & 2 & 0.3480 & 1 & 0.5268 & 1 & 0.4393 & 1 \\
\hline \multirow{3}{*}{ B } & Vilnius & 1,0000 & 1 & 0.6764 & 1 & 1.0000 & 1 & 0.8921 & 1 \\
\hline & Weimar & 0.1943 & 3 & 0.1026 & 3 & 0.0000 & 3 & 0.0990 & 3 \\
\hline & Montreal & 0.4042 & 2 & 0.2210 & 2 & 0.2524 & 2 & 0.2925 & 2 \\
\hline \multirow{3}{*}{$\mathrm{C}$} & Vilnius & 0.5505 & 2 & 0.2211 & 3 & 0.2880 & 3 & 0.3532 & 3 \\
\hline & Weimar & 0.5335 & 3 & 0.3139 & 2 & 0.3691 & 2 & 0.4055 & 2 \\
\hline & Montreal & 0.8114 & 1 & 0.4650 & 1 & 0.8526 & 1 & 0.7097 & 1 \\
\hline \multirow{3}{*}{$\mathrm{D}$} & Vilnius & 0.8924 & 1 & 0.3841 & 1 & 0.6137 & 2 & 0.6300 & 1 \\
\hline & Weimar & 0.6734 & 3 & 0.2800 & 3 & 0.3155 & 3 & 0.4230 & 3 \\
\hline & Montreal & 0.7688 & 2 & 0.3360 & 2 & 0.6194 & 1 & 0.5747 & 2 \\
\hline \multirow{3}{*}{$\mathrm{E}$} & Vilnius & 0.6002 & 2 & 0.3986 & 1 & 0.2570 & 3 & 0.4186 & 2 \\
\hline & Weimar & 0.4748 & 3 & 0.2095 & 3 & 0.2630 & 2 & 0.3158 & 3 \\
\hline & Montreal & 0.6605 & 1 & 0.3919 & 2 & 0.5566 & 1 & 0.5364 & 1 \\
\hline
\end{tabular}


Calculations were performed using an Excel spreadsheet. After a multi-criteria evaluation, the average value of the obtained results was calculated. The results are shown in the diagram (Figure 7).

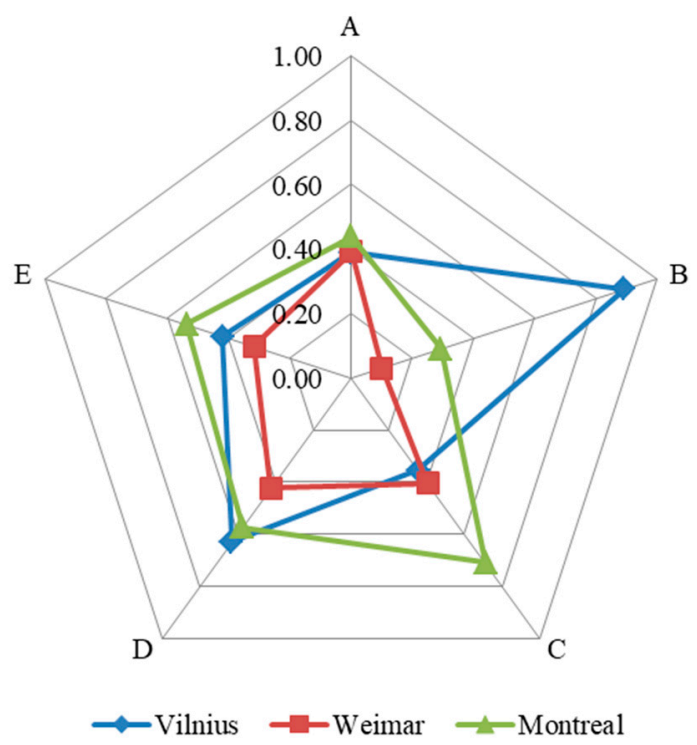

Figure 7. The smartness level evaluation of Vilnius, Weimar, and Montreal cities according to separate factors.

Assessing the cities by individual factors shows that there is no absolutely leading city. According to factor A-motor travel and congestion reduction measures, Montreal ranks first, Vilnius second, and Weimar third. According to factor B-pollution abatement measures, Vilnius ranks first, Montreal second, and Weimar third. According to factor $\mathrm{C}$ - travel safety and accident reduction measures, Montreal ranks first, Weimar ranks second, and Vilnius ranks third. According to factor D-traffic management tools and services, Vilnius ranks first, Montreal ranks second, and Weimar ranks third. According to the factor E-smart infrastructure measures, Montreal ranks first, Vilnius second, and Weimar third.

The smartness level of the Vilnius, Weimar, and Montreal mobility systems was assessed using the generalised significance of the integrated indicators in the MCDM methods (Table 4).

Table 4. Calculation results of MCDM methods.

\begin{tabular}{|c|c|c|c|c|c|c|c|c|}
\hline \multirow{3}{*}{ City } & \multicolumn{6}{|c|}{ MCDM Method } & \multirow{2}{*}{\multicolumn{2}{|c|}{ Average }} \\
\hline & \multicolumn{2}{|c|}{ SAW } & \multicolumn{2}{|c|}{ COPRAS } & \multicolumn{2}{|c|}{ TOPSIS } & & \\
\hline & Value & Place & Value & Place & Value & Place & Value & Place \\
\hline Vilnius & 0.6908 & 2 & 0.3751 & 2 & 0.4634 & 2 & 0.5098 & 2 \\
\hline Weimar & 0.5111 & 3 & 0.2463 & 3 & 0.3810 & 3 & 0.3795 & 3 \\
\hline Montreal & 0.6979 & 1 & 0.3786 & 1 & 0.5805 & 1 & 0.5523 & 1 \\
\hline
\end{tabular}

The evaluation of Vilnius, Weimar, and Montreal according to the SAW, COPRAS, and TOPSIS methods, and the best of the knowledge that was gathered from the literature, shows that the "smartest" mobility system is in Montreal, and the "least smart" is in Weimar.

\section{Discussion and Conclusions}

This study presents a smart mobility system evaluation model that ranks urban mobility smartness and identifies a leading city. Using the proposed evaluation model, 
the assessment of the mobility system and the comparison of cities are performed using MCDM methods. Multi-criteria evaluation can be performed both on the basis of individual factors and on the basis of integrated indicators obtained by synthesising the significance of factors and indicators. Advantages of the model: a detailed set of indicators; if necessary, indicators can be changed from quantitative to qualitative and vice versa; the smartness of the mobility system can be compared without imposing any special requirements on cities.

The selection of experts is an important factor in model development. Experts competence must be strictly taken into account-many years of practical and/or scientific experience are desirable as well as having in-depth knowledge of civil engineering and/or transport engineering, etc. The limitation is that expert opinions often depend on the positions they hold, on the public or private sector in which they work, and on which topics the experts have a deeper knowledge of the smart urban mobility system, and so on. The collection of accurate and up-to-date data is directly relevant to the evaluation results. Unfortunately, there are no databases where all the required data can be found. Data collection requires requests from various public and private companies, which may not provide data for a long time or simply refuse to share. Freely available data online may be out of date or not available at all. It is difficult to find professionals from foreign cities to volunteer time to help gather data on their city. Additionally, it takes a very long time as many institutions need to be contacted.

There are several directions for future research. It would be useful to update the survey of experts and to include experts from different countries. This may affect the significance of factors and indicators, which would also change the assessment of smart urban mobility system. Additionally, this research could be extended by assessing and comparing more cities. Further research could show whether smaller cities are less smart, whether there are correlations between cities on different continents, and so on. Expanding the number of cities evaluated could provide more insights into the smart urban mobility system depending on size, continent, country, population density, most-developed areas, and so on. Even if reliable MCDM methods were used for the proposed model, it would be interesting to apply newer MCDM methods and see if the results change.

Author Contributions: Conceptualization, M.T. and S.Z.; methodology, S.Z.; formal analysis, S.Z.; investigation, M.T. and S.Z.; data curation, M.T. and S.Z.; writing-original draft preparation, O.S. and S.Z.; writing — review and editing, M.B. and M.T.; visualisation, O.S. and S.Z.; supervision, M.B. All authors have read and agreed to the published version of the manuscript.

Funding: This research has received funding from Vilnius Gediminas Technical University and CIRRELT, University of Montreal.

Institutional Review Board Statement: Not applicable.

Informed Consent Statement: Not applicable.

Data Availability Statement: Not applicable.

Conflicts of Interest: The authors declare no conflict of interest.

\section{References}

1. Sharifi, A.; Kawakubo, S.; Milovidova, A. Urban sustainability assessment tools: Toward integrating smart city indicators. In Urban Systems Design; Yamagata, Y., Yang, P.P.J., Eds.; Elsevier: Amsterdam, The Netherlands, 2020; Chapter 11; pp. 345-372. [CrossRef]

2. Quiroga, E.; Gutiérrez, K. Smart mobility: Opportunities and challenges for colombian cities. Adv. Sci. Technol. Eng. Syst. J. 2021, 6, 332-338. [CrossRef]

3. Ogrodnik, K. Multi-criteria analysis of smart cities in Poland. Geogr. Pol. 2020, 93, 163-181. [CrossRef]

4. Sojda, A. Smart city index based on topsis method. Sci. Pap. Sil. Univ. Technol. Organ. Manag. Ser. 2020, 148, 709-718. [CrossRef]

5. Ali, N. Evaluating sustainable urban transport systems: A Review study for the identification of smart mobility indicators. Trans. Transp. Sci. 2021, 12, 16-23. [CrossRef] 
6. Sunardi, H.; Sulistyo, S.; Mustika, I. Analysis of smart mobility readiness in Banjarmasin City. In Proceedings of the International Conference on Creative Economics, Tourism and Information Management (ICCETIM 2019)—Creativity and Innovation Developments for Global Competitiveness and Sustainability 2020, Yogyakarta, Indonesia, 17-18 July 2019; Volume 1, pp. 158-162. [CrossRef]

7. Paiva, S.; Ahad, M.A.; Tripathi, G.; Feroz, N.; Casalino, G. Enabling technologies for urban smart mobility: Recent trends, opportunities and challenges. Sensors 2021, 21, 2143. [CrossRef] [PubMed]

8. Nagy, S.; Csiszár, C. The quality of smart mobility: A systematic review. Sci. J. Silesian Univ. Technol. Ser. Transp. 2020, 109, 117-127. [CrossRef]

9. Bıyık, C.; Abareshi, A.; Paz, A.; Ruiz, R.; Battarra, R.; Rogers, C.; Lizarraga, C. Smart mobility adoption: A review of the literature. J. Open Innov. Technol. Mark. Complex. 2021, 7, 146. [CrossRef]

10. Pereira, R.C.; Branchi, B.A.; Ferreira, D.H.L. Sustainable urban mobility diagnosis: Applicability of a composite index. RISUS J. Innov. Sustain. 2021, 12, 16-29. [CrossRef]

11. Benevolo, C.; Dameri, R.P.; D'Auria, B. Smart mobility in smart city. Action taxonomy, ICT intensity and public benefits. In Empowering Organizations. Lecture Notes in Information Systems and Organisation; Torre, T., Braccini, A.M., Spinelli, R., Eds.; Springer: Cham, Switzerland, 2016; Volume 11, pp. 13-28. [CrossRef]

12. Zapolskytè, S.; Burinskienè, M.; Trépanier, M. Evaluation criteria of smart city mobility system using MCDM method. Balt. J. Road Bridg. Eng. 2020, 15, 196-224. [CrossRef]

13. Podvezko, V.; Podviezko, A. Kriteriju reikšmingumo nustatymo metodai. Liet. Mat. Rink. Liet. Mat. Draugijos Darb. 2014, 55, 111-116.

14. Sivilevičius, H. Application of expert evaluation method to determine the importance of operating asphalt mixing plant quality criteria and rank correlation. Balt. J. Road Bridg. Eng. 2011, 6, 48-58. [CrossRef]

15. Zavadskas, E.K.; Antucheviciene, J.; Vilutiene, T.; Adeli, H. Sustainable decision-making in civil engineering, construction and building technology. Sustainability 2018, 10, 14. [CrossRef]

16. Zavadskas, E.K.; Antucheviciene, J.; Turskis, Z.; Adeli, H. Hybrid multiple-criteria decision-making methods: A review of applications in engineering. Sci. Iran. 2016, 23, 1-20. [CrossRef]

17. Zavadskas, E.K.; Govindan, K.; Antucheviciene, J.; Turskis, Z. Hybrid multiple criteria decision-making methods: A review of applications for sustainability issues. Econ. Res. Ekon. Istraživanja 2016, 29, 857-887. [CrossRef]

18. Zapolskytè, S. Išmaniojo Miesto Susisiekimo Sistemos Infrastruktūros Kompleksinis Vertinimo Modelis (Complex Evaluation Model of Smart City Mobility System Infrastructure). Ph.D. Dissertation, Vilnius Gediminas Technical University, Vilnius, Lithuania, 16 December 2021.

19. Appleton, B.; Davies., M.; Tansey, J. Green Apple Canada 2008: SMART Transportation Ranking Report; Sauder School of Business, University of British Columbia: Vancouver, BC, Canada, 2008.

20. Balducci, F.; Ferrara, A. Using urban environmental policy data to understand the domains of smartness: An analysis of spatial autocorrelation for all the Italian chief towns. Ecol. Indic. 2018, 89, 386-396. [CrossRef]

21. Battarra, R.; Gargiulo, C.; Tremiterra, M.R.; Zucaro, F. Smart mobility in Italian metropolitan cities: A comparative analysis through indicators and actions. Sustain. Cities Soc. 2018, 41, 556-567. [CrossRef]

22. Battarra, R.; Zucaro, F.; Tremiterra, M.R. Smart mobility and elderly people. Can ICT make city more accessible for everybody? J. Land Use Mobil. Environ. 2018, 2, 23-42. [CrossRef]

23. Boselli, R.; Cesarini, M.; Mercorio, F.; Mezzanzanica, M. Applying the AHP to smart mobility services: A case study. In Proceedings of the 4th International Conference on Data Management Technologies and Applications 2015, (KomIS-2015), Colmar Alsace, France, 20-22 July 2015.

24. Costa, P.; Neto, G.M.; Bertolde, A.I. Urban mobility indexes: A brief review of the literature. Transp. Res. Procedia 2017, 25, 3645-3655. [CrossRef]

25. Debnath, A.K.; Chin, H.C.; Haque, M.; Yuen, B. A methodological framework for benchmarking smart transport cities. Cities 2014, 37, 47-56. [CrossRef]

26. Garau, C.; Masala, F.; Pinna, F. Cagliari and smart urban mobility: Analysis and comparison. Cities 2016, 56, 35-46. [CrossRef]

27. Girardi, P.; Temporelli, A. Smartainability: A methodology for assessing the sustainability of the smart city. Energy Procedia 2017, 111, 810-816. [CrossRef]

28. Jiang, T.; Wu, Z.; Song, Y.; Liu, X.; Liu, H.; Zhang, H. Sustainable transport data collection and application: China urban transport database. Math. Probl. Eng. 2013, 2013, 879752. [CrossRef]

29. Litman, T. Sustainable Transportation Indicators. A Recommended Program to Define a Standard Set of Indicators for Sustainable Transportation Planning. 2008, p. 13. Available online: https:/ / www.vtpi.org/sustain/sti.pdf (accessed on 10 September 2021)

30. Lopez-Carreiro, I.; Monzon, A. Evaluating sustainability and innovation of mobility patterns in Spanish cities. Analysis by size and urban typology. Sustain. Cities Soc. 2018, 38, 684-696. [CrossRef]

31. Marletto, G.; Mameli, F. A participative procedure to select indicators of policies for sustainable urban mobility. Outcomes of a national test. Eur. Transp. Res. Rev. 2012, 4, 79-89. [CrossRef]

32. Orlowski, A.; Romanowska, P. Smart cities concept: Smart mobility indicator. Cybern. Syst. 2019, 50, 118-131. [CrossRef]

33. Pinna, F.; Masala, F.; Garau, C. Urban policies and mobility trends in Italian smart cities. Sustainability 2017, 9, 494. [CrossRef] 
34. Reiber, L.; Huang, G. Comparing study on smart city strategies in Berlin and Shanghai, advances in economics. Bus. Manag. Res. 2018, 56, 419-422. [CrossRef]

35. Savelson, A.; Colman, R.; Litman, T.; Walker, S.; Parmenter, R. The GPI Transportation Accounts: Sustainable Transportation in Nova Scotia. Canada. 2006. Available online: http://www.gpiatlantic.org/publications/summaries/transportationsumm.pdf (accessed on 15 September 2020).

36. Tafidis, P.; Sdoukopoulos, A.; Pitsiava-Latinopoulou, M. Sustainable urban mobility indicators: Policy versus practice in the case of Greek cities. Transp. Res. Procedia 2017, 24, 304-312. [CrossRef]

37. Wibowo, S.; Grandhi, S. A multicriteria analysis approach for benchmarking smart transport cities. In Proceedings of the Science and Information Conference 2015, London, UK, 28-30 July 2015; pp. 94-101. [CrossRef]

38. Adiyarta, K.; Napitupulu, D.; Mohammad Syafrullah, M.; Mahdiana, D.; Rusdah, R. Analysis of smart city indicators based on prisma: Systematic review. In Proceedings of the IOP Conference Series, Materials Science and Engineering, 3rd Nommensen International Conference on Technology and Engineering 2019 (3rd NICTE), Nommensen HKBP University, Medan, Indonesia, 25-26 July 2019. [CrossRef]

39. Chao, A.L.; Gallego, A.C.; Lopez-Chao, V.; Alvarellos, A. Indicators framework for sustainable urban design. Atmosphere 2020, 11, 1143. [CrossRef]

40. Kusumawardani, D.; Saintika, Y.; Romadlon, F. The smart mobility insight of bus rapid transit (BRT) trans jateng purwokertopurbalingga ridership. In Proceedings of the International Conference on ICT for Smart Society (ICISS) 2021, Bandung, Indonesia, 2-4 August 2021; pp. 1-5. [CrossRef]

41. Castillo, H.; Pitfield, D.E. ELASTIC-A methodological framework for identifying and selecting sustainable transport indicators. Transp. Res. Part D Transp. Environ. 2010, 15, 179-188. [CrossRef]

42. Alexopoulos, C.; Pereira, G.V.; Charalabidis, Y.; Madrid, L. A taxonomy of smart cities initiatives. In Proceedings of the 12th International Conference on Theory and Practice of Electronic Governance 2019 (ICEGOV2019), Melbourne, VIC, Australia, 3-5 April 2019; pp. 281-290. [CrossRef]

43. Carli, R.; Dotoli, M.; Pellegrino, R.; Ranieri, L. Measuring and managing the smartness of cities: A framework for classifying performance indicators. In Proceedings of the IEEE International Conference on Systems, Man, and Cybernetics 2013, Washington, DC, USA, 13-16 October 2013; pp. 1288-1293. [CrossRef]

44. Boukerche, A.; Coutinho, R.W.L. Crowd management: The overlooked component of smart transportation systems IEEE Commun. Mag. 2019, 57, 48-53. [CrossRef]

45. Farooq, A.; Xie, M.; Stoilova, S.; Ahmad, F. Multicriteria evaluation of transport plan for high-speed rail: An application to Beijing-Xiongan. Math. Probl. Eng. 2019, 2019, 8319432. [CrossRef]

46. Li, X.; Fong, P.S.; Dai, S.; Li, Y. Towards sustainable smart cities: An empirical comparative assessment and development pattern optimization in China. J. Clean. Prod. 2019, 215, 730-743. [CrossRef]

47. Macedo, J.; Rodrigues, F.; Tavares, F. Urban sustainability mobility assessment: Indicators proposal. Energy Procedia 2017, 134, 731-740. [CrossRef]

48. Sdoukopoulos, A.; Nikolaidou, A.; Pitsiava-Latinopoulou, M.; Papaioannou, P. A methodological approach for the assessment of sustainable urban mobility indicators using social media data. In Proceedings of the Sixth International Conference on Environmental Management, Engineering, Planning \& Economics 2017, Thessaloniki, Greece, 25-30 June 2017; pp. 1015-1024. Available online: https:/ / www.researchgate.net/publication/320614937 (accessed on 13 November 2020).

49. Sureshchandra, S.M.; Bhavsar, J.J.; Pitroda, J.R. Review on identification of success factors for designing of smart cities. IJSTE Int. J. Sci. Technol. Eng. 2016, 2, 125-133.

50. Kristiningrum, E.; Kusumo, H. Indicators of smart city using SNI ISO 37122:2019. IOP Conf. Ser. Mater. Sci. Eng. 2021, 1096, 012013. [CrossRef]

51. Razmjoo, A.; Nezhad, M.; Kaigutha, L.; Marzband, M.; Mirjalili, S.; Pazhoohesh, M.; Memon, S.; Ehyaei, M.; Piras, G. Investigating smart city development based on green buildings, electrical vehicles and feasible indicators. Sustainability 2021, $13,7808$. [CrossRef]

52. Petrova-Antonova, D.; Ilieva, S. Smart cities evaluation-A survey of performance and sustainability indicators. In Proceedings of the 44th Euromicro Conference on Software Engineering and Advanced Applications, Prague, Czech Republic, 29-31 August 2018. [CrossRef]

53. Mohmmed, A.G.M.; Osman, S.E.F. Smart city \& internet of things. Int. Res. J. Comput. Sci. (IRJCS) 2017, 5, $238-241$.

54. Saaty, T.L. Decision making with the analytic hierarchy process. Int. J. Serv. Sci. 2008, 1, 83-98. [CrossRef] 